УДК 681.2 .08

DOI 10.36910/6775-2313-5352-2021-18-20

Чуйко М.М., Витвицька Л.А.

Івано-Франківський національний технічний університет нафти і газу

\title{
ЕКСПРЕС-МЕТОД КОНТРОЛЮ ЯКОСТІ ПОВЕРХНЕВО-АКТИВНИХ РЕЧОВИН ДЛЯ ІНТЕНСИФІКАЦІЇ НАФТОГАЗОВИДОБУТКУ
}

Проаналізовано прочес витіснення нафтового флюїду з пор нафтогазоносних порід, встановлено параметри, за якими визначається якість поверхнево-активних речовин (ПАР), використовуваних для інтенсифікаиї нафтовіддачі. Обгрунтовано необхідність здійснювати підбір конкретного виду ПАР для конкретних порід нафтогазоносних пластів. Запропоновано метод експрес-контролю якості ПАР та розроблено конструкиію пристрою для реалізаиіі методу.

Ключові слова: поверхнево-активні речовини, нафтогазоносні породи, адгезійнокогезійна взаємодія, змочування, витіснення рідини, пори

Вступ та постановка проблеми. Для інтенсифікації нафтогазовіддачі в процесі нафтогазовидобування вирішальну роль відіграють поверхнево-активні речовини (надалі ПАР). Ця роль полягає у покращенні змочування пластовою рідиною (флюїдом) внутрішніх поверхонь пор нафтогазоносних порід, що призводить до підвищення ступеня витіснення нафтопродукта до гирла свердловини. В силу існуючої значної кількості видів ПАР, виготовлених на основі різноманітних хімічних елементів та різної концентрації складників, а також різноманітних порід нафтогазоносних пластів виникає необхідність встановлення відповідності конкретних ПАР для конкретних порід. Тому контроль поверхневих властивостей ПАР при встановленні доцільності їх вибору є актуальною задачею в нафтогазовидобуванні.

Мета роботи. Ступінь змочування рідиною поверхні твердого тіла визначається за крайовим кутом змочування, який залежить від поверхневих натягів на границях розділу всіх середовищ, які беруть участь у процесі витіснення нафтопродукту: рідкого, твердого та газоподібного [1]. Зниження значення ККЗ призводить до швидшого руху рідини всередині пор, а значить, і до інтенсивнішої нафтовіддачі. Тому якість ПАР і визначається саме за зменшенням поверхневого натягу рідини, тобто за зниженням значення крайового кута змочування, що і приводить до збільшення нафтовіддачі. Однак процес інтенсифікації, тобто відтікання нафти з пор породи залежить також і від в'язкості рідини, від шорсткості внутрішніх поверхонь пор, їх щільності та ступеня накладання пор між собою. Саме тому ставиться задача розроблення методу для проведення комплексного експрес-контролю якості ПАР, використовуваних для інтенсифікації нафто газовидобутку 3 конкретно взятих пластів порід.

Результати роботи. При видаленні рідини 3 твердої поверхні можливий або адгезійний відрив по межі рідина - тверде тіло, або когезійний відрив, коли порушується межа рідина рідина. В деяких випадках має місце адгезійно-когезійний відрив. Під адгезією рідини мають на увазі взаємодію рідкої і твердої фаз на межі розділу цих фаз. Величину адгезійної взаємодії можна визначити в процесі видалення рідині з поверхні твердого тіла.

Адгезійна взаємодія між рідкою і твердою фазами розповсюджується на невелику відстань в глиб рідини. Ця відстань вимірюється розмірами молекул або дещо більше. У міру видалення шару рідини від поверхні твердого тіла адгезійна взаємодія зменшується, поступаючись місцем когезійній. Когезія рідини - це взаємодія між молекулами (атомами або іонами) в об'ємі рідкої фази.

Рідина володіє мінімальною зсувною міцністю. Тому величина адгезії і когезії при видаленні рідини може бути визначена лише для граничного шару рідини. У практиці можуть бути реалізовані два випадки взаємодії рідини з твердим тілом: адгезія обмеженого об'єму рідини, тобто адгезія краплі, і адгезія великої кількості рідини [2].

У разі контакту великої кількості рідини з твердою поверхнею робота адгезії вимірюється з розрахунку на одиницю площі контакту рідина - тверде тіло. Робота, яка визначає взаємодію рідини 3 твердою поверхнею і необхідна для роз'єднання контактуючих тіл, дорівнює роботі адгезії $W_{a}$, помноженої на площу зіткнення рідини з твердим тілом: 


$$
W=W_{a} S .
$$

У разі адгезії краплі під величиною $S$ слід мати на увазі площу контакту краплі 3 поверхнею. Таким чином, для визначення роботи, що виникає при контакті рідини 3 твердим тілом, необхідно знати площу контакту іiі з поверхнею. Ця площа визначається здатністю рідини змочувати тверді поверхні.

Адгезія і змочування - це дві сторони одного і того ж явища, що виникає при контакті рідини з твердою поверхнею. Адгезія обумовлює взаємодію між твердим тілом і рідиною, що знаходиться у контакті з ним, а змочування - це явище, яке має місце в результаті цієї взаємодії.

Видалення рідини з поверхні не можна здійснити тими методами, які застосовуються у разі адгезії частинок, тобто шляхом прикладання зовнішньої сили, що перевищує адгезійну взаємодію. Під дією зовнішньої відриваючої сили (наприклад, відцентровою) відбувається деформація краплі і зміна площі їі контакту з поверхнею. У зв'язку з цим оцінка величини адгезії рідини по силі, як це має місце у разі адгезії частинок, не придатна. Тому адгезія рідини оцінюється роботою $W_{a}$, яку треба витратити для відриву рідині від твердої поверхні, т.б. для відновлення початкового стану контактуючих тіл.

Для оцінки адгезійної взаємодії застосовують і інші показники. Окрім крайового кута змочування $\theta$ піддається експериментальному визначенню поверхневий натяг рідини на границі іiі розділу з газовим середовищем $\sigma_{p 2}$. У зв'язку з цим використовують добуток $\sigma_{p 2}$ на $\cos \theta$, який називають енергією змочування, або адгезійною напругою:

$$
W_{e}=\sigma_{p 2} \cdot \cos \theta \text {. }
$$

Адгезійна напруга на гідрофільній поверхні сприяє розтіканню краплі, а на гідрофобній перешкоджає розтіканню.

При контакті рідини з твердою поверхнею вільна поверхнева енергія рівна поверхневому натягу на границі розділу рідина - тверде тіло $\gamma_{p m}$, а після роз'єднання тіл вона стає рівною сумі поверхневих натягів на границях розділу рідина - газ та тверде тіло - газ $\sigma_{p 2}+\sigma_{m 2}$. Різниця між цими величинами і $є$ робота адгезії.

$$
W_{a}=\sigma_{p 2}+\sigma_{m 2}-\gamma_{p m} .
$$

3 урахуванням рівняння Юнга [3] залежність (3), яка представляє собою роботу адгезії, приведену до одиниці площі, можна записати таким чином:

$$
W_{a}=\sigma_{p 2} \cdot(1+\cos \theta) \text {. }
$$

Як випливає з рис. 1, робота адгезії зменшується із збільшенням крайового кута. Подібна закономірність виявлена у разі змочування водою льоду, а також при змочуванні водою різних поверхонь. Так, при збільшенні крайового кута на полімерних матеріалах від 0 до $108^{\circ}$ робота адгезії зменшується від 20 до 1,5 кгс/см².

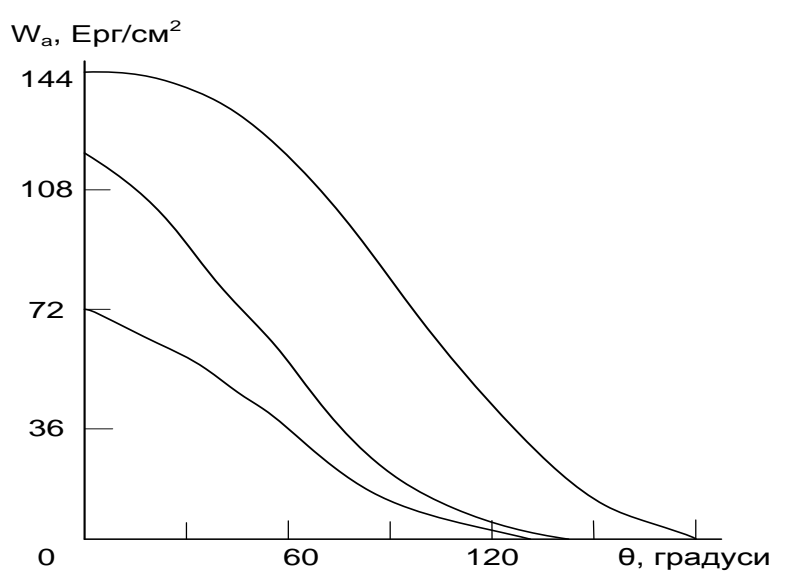

Рис. 1. Залежність між роботою адгезії і крайовим кутом змочування

Часто роботу адгезії зіставляють з роботою когезії. Робота когезії дорівнює тій роботі, яку треба прикласти, щоб подолати взаємодію між собою молекул рідини. При цьому утворюються дві поверхні розділу фаз рідина - газ. Тому робота когезії дорівнює подвоєному значенню вільної поверхневої енергії (поверхневого натягу) рідких фаз, що утворилися, тобто:

$$
W_{\kappa}=2 \sigma_{p 2} .
$$


При визначенні роботи, яку необхідно витратити для видалення рідині, слід роботу адгезії помножити на площу контакту рідини з твердою поверхнею.

Можливий інший вираз адгезії, коли робота адгезії відноситься до одиниці поверхні сферичної краплі, яка стикається з газовим середовищем. Тоді роботу $W$, що витрачається для видалення краплі, слід розділити на площу контакту $S$ ' з газовим (а не твердим) середовищем.

Також роботу адгезії можна визначати за правилом Антонова [4], яке формулюється таким чином: якщо рідини обмежено розчинені одна в одній, то поверхневий натяг на границі рідина - рідина наближено рівний різниці поверхневого натягу взаємно насичених рідин на межі цих рідин з повітрям. Хоча це правило виведене для рідин, але його можна застосовувати для випадку адгезії рідини на твердій поверхні при повному ії змочуванні. Щодо адгезії рідини на твердій поверхні правило Антонова можна представити в наступному вигляді:

$$
\gamma_{p m}=\sigma_{p 2}-\sigma_{m 2}
$$

тобто поверхневий натяг на межі рідини з твердим тілом рівний по абсолютній величині різниці поверхневих натягів рідкої і твердої фаз на межі з газовим середовищем.

У зв'язку з тим, що при розтіканні краплі поверхня розділу рідина - газ змінюється значно менше, ніж поверхня розділу рідина - тверде тіло, можна вважати, що робота адгезії при розтіканні краплі $є$ повнішою характеристикою роботи адгезії при розтіканні більшої кількості рідини. Проте при вирішенні задачі вибору виду ПАР для інтенсифікації нафтовіддачі визначення роботи адгезії при відриві з поверхні пор однієї краплі $є$ більш складною задачею і при цьому не відтворюються процеси витіснення нафтопродуктів у пластових умовах .

Тому пропонується метод комплексного контролю якості ПАР, який полягає у визначенні адгезійно-когезійної роботи шляхом визначення швидкості відтікання рідини із зразка породи. Дана фізична величина залежить від декількох величин: змочування рідиною твердого тіла, поверхневих натягів рідини, твердого тіла, в'язкості рідини, а також від шорсткості поверхні твердого тіла. Оскільки нафтогазоносні породи відрізняються за своєю структурою, розміром пор та ступенем змочування флюїдом стінок пор, який залежить від складу породи, розмірів пор, щільності їх розташування та пластового тиску і температури, виникає необхідність контролю якості ПАР і його вибору для нафтогазоносного пласта конкретної породи. За даним методом здійснюється комплексна оцінка ПАР на п'ятьох зразках однакових розмірів однієї і тієї ж породи. Зразки породи висотою 10 мм отримуються шляхом розрізання керна досліджуваної породи.

Контроль швидкості відтікання здійснюється шляхом неперервної реєстрації зміни об'єму досліджуваної рідини, яка відтікає з поверхні нахиленого зразка і потрапляє у оптично прозору мірну ємність.

На рисунку 2 подана функціональна схема пристрою, за допомогою якого реалізується запропонований метод.

Пристрій складається 3 трьох основних вузлів різного функціонального призначення. Вузол 1 (електромеханічний блок) здійснює прецизійне переміщення поршня дозатора для нанесення досліджуваної ПАР на зразок породи. Вузол 2 (вимірювальний блок) призначений для вимірювання об'єму рідини, яка стікає із зразка у мірну ємність. У вузлі 3 (блок оброблення та керування) здійснюється реєстрація зміни об'єму ПАР і порівняння часових кривих різних рідин, а також керування процесом роботи дозатора та всього пристрою.

Прецизійне переміщення дозатора Д (шприца) здійснюється за допомогою чотириобмоткового крокового двигуна КД, вал якого з'єднаний з передавальним механізмом ПМ. Обертовий момент 3 валу двигуна через муфтове з'єднання типу "квадрат" передається на муфту гвинтового з'єднання, де перетворюється в поступальний рух гвинта 3 напівсферичним наконечником, який кінематично зв'язує гвинт із підпружиненим штовхачем, який зв'язаний із поршнем дозатора. Таким чином ПМ перетворює обертовий рух валу в поступальний рух поршня дозатора. При русі поршня вниз крапля ПАР видавлюється з голки дозатора, при цьому крапельно наноситься досліджувана рідина на пористу поверхню керна. Часовий інтервал між двома видавлюваннями краплі складає час, необхідний для адсорбції рідини пористим тілом (3 хв), вимірювання кількості рідини, котра натекла у колбу-мірник М і подачі серії імпульсів для наступного кроку валу двигуна. Вмикання, реверс чи зупинка двигуна керується персональним комп'ютером ПК через блок управління двигуном БУД почерговою подачею на його обмотки імпульсів напруги 5В, силою струму $1 \mathrm{~A}$ і довжиною близько 10 мс.

( ) Чуйко М.М. к.т.н., Витвицька Л.А., к.т.н., доц. 


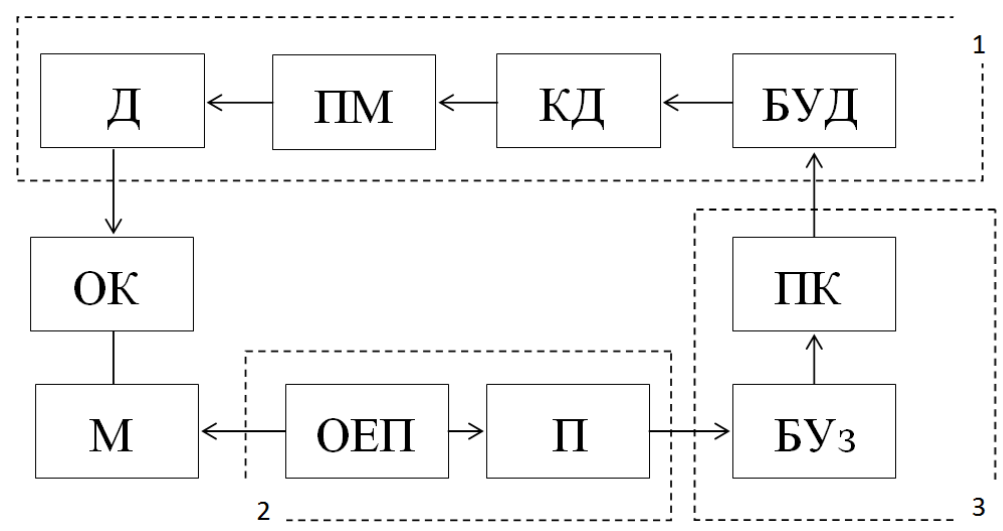

Рис. 2 . Функціональна блок-схема розробленого пристрою

Застосований в пристрої кроковий двигун при подачі одного імпульса на відповідну обмотку дає можливість отримати мінімальний кут обертання на його валу рівний 108 кутових хвилин. Використання крокового двигуна дає можливість здійснювати переміщення поршня 3 дискретністю $0,5 / 256$, оскільки один повний оберт валу крокового двигуна, який здійснюється при подачі 256 імпульсів на його обмотку збудження, відповідає переміщенню поршня на 0,5 мм. Тому дозований мінімальний об'єм краплі рівний:

$$
V=\frac{\pi D^{2}}{4} \cdot \frac{0.5}{256}=\frac{3,14 \cdot 6^{2}}{4} \cdot \frac{0.5}{256}=0.055 \mathrm{MM}^{3}
$$

де $D$ - внутрішній діаметр корпусу шприца.

Об’єкт контролю ОК, тобто зразок породи, отриманий $з$ керна, встановлюється на нахилену під кутом $15^{\circ}$ основу, розташовану на столі. У нижньому кінці стола розміщений отвір, через який натікає у скляну колбу-мірник $\mathrm{M}$ рідина, що пройшла через пори досліджуваного зразка. Стіл і колба розташовані на платформі. Закріплення основи і стола на платформі здійснюється через різьбові з'єднання, що дає можливість регулювати за допомогою нівеліра розташування основи на столі під необхідним кутом для усунення похибки, викликаної невідповідністю нахилу площини зразка, при цьому колба розташовується чітко горизонтально.

Кількість рідини у колбі визначається опто-електронним перетворювачем ОЕП сигнал 3 якого підсилюється підсилювачем П і через блок узгодження БУз подається на ПК для реєстрації та порівняння з часовими залежностями зміни об'єму рідини у колбі при дослідженні інших зразків та інших ПАР. Через клавіатуру ПК вводяться команди про початок і кінець вимірювання, а також номер зразка та вид ПАР. В ПК формується висновок про якість ПАР стосовно досліджуваного зразка породи, отриманого з керна, Чим вища швидкість натікання розчину ПАР у мірник, тобто чим більший кут нахилу кривої зміни в часі кількості рідини у мірнику, що відповідає кращому змочуванню ПАР стінок пор породи, тим інтенсивнішим буде рух флюїду і краща нафтовіддача пласта.

\section{Висновки}

1. На основі аналізу процесу інтенсифікації витіснення флюїду з пор нафтогазоносної породи за допомогою поверхнево-активних речовин запропоновано проводити експресконтроль процесу витіснення на основі вимірювання динаміки витіснення ПАР 3 пор досліджуваного зразка породи. порівнювати динамічні залежності для різних ПАР і визначати доцільність вибору конкретного виду ПАР для конкретної породи

2. Розроблено конструкцію пристрою, який дозволяє здійснювати вибір найбільш оптимального типу та концентрації розчину ПАР для витіснення ним нафтового флюїду з пор породи.

\section{Література}

1. Becky L. and Abraham M. The exponential power law: partial wetting kinetics and dynamic contact angles. Colloid Surfaces A: Physicochem. Eng. Aspects. 2014. Vol. 250. Pp. 409-414.

2. Neumann A.W. Applied surface thermodynamics. - 2nd ed. / A.W. Neumann, Robert David, Yi Zuo. - N.Y.: CRC Press Taylor \& Francis Group, 2011. -768 p.

3.Зенгнил Э. Физика поверхности /Э. Зенгнил - М.: Мир., 1990. - 536 с. 
4.Киселев В.Ф. Основи физики поверхности твердого тела / В.Ф. Киселев, С.Н. Козлов, А.В. Зотеев - М.: Изд-во Моск. ун-та. - Физфак МГУ, 1999. - 284 с.

Chuyko M. M., Vytvytska L.A.

Ivano-Frankivsk National Technical University of Oil and Gas

\section{EXPRESS METHOD OF SURFACTANTS QUALITY CONTROL FOR INTENSIFICATION OF OIL AND GAS PRODUCTION}

The process of displacement of oil fluid from the pores of oil and gas rocks is analyzed, the parameters for determining the quality of surfactants used to intensify oil recovery are established. The necessity to select a specific type of surfactant for specific rocks of oil and gas formations is substantiated. The method of express quality control of surfactants is offered and the design of the device for realization of a method is developed

Key words: surfactants, oil and gas rocks, adhesive-cohesive interaction, wetting, liquid displacement, pores

Чуйко М.М., Витвицкая Л.А.

Ивано-Франковский национальный технический университет нефти и газа

\section{ЭКСПРЕСС-МЕТОД КОНТРОЛЯ КАЧЕСТВА ПОВЕРХНОСТНО-АКТИВНЫХ ВЕЩЕСТВ ДЛЯ ИНТЕНСИФИКАЦИИ НЕФТЕГАЗОДОБЫЧИ}

Проанализированы процессы вытеснения нефтяного флюида из пор нефтегазоносных пород, установлено параметры, по которым определяется качество поверхностно-активных веществ, используемых для интенсификации нефтеотдачи. Обоснована необходимость осуществлять подбор конкретного вида ПАР для конкретных пород нефтегазоносных пластов. Предложен метод экспресс-контроля качества ПАР и разработана конструкция устройства для реализации метода

Ключевые слова: поверхностно-активные вещества, нефтегазоносные породы, адгезийно- когезийное взаимодействие, смачивание, вытеснение жидкости, поры 